\title{
PÄÄKIRJOITUS: ANTROPOSEENI EROJEN NÄYTTÄMÖNÄ
}

Vuonna 1873 italialainen entinen katolinen pappi, sittemmin geologiksi ryhtynyt Antonio Stoppani ehdotti kirjassaan Corso di Geologia, että käynnissä oleva geologinen ajanjakso tulisi nimetä ihmisen mukaan. "Antropotsooinen aikakausi on alkanut: eikä geologeista ole ennustamaan sen loppua”, Stoppani julisti ja kuvaili kattavasti, kuinka ihmisen historiallisesti kasautuneet jäljet olivat nähtävissä kaikkialla luonnossa. Ihminen oli hakannut metsät, kääntänyt joenvirtausten suunnat, porannut itsensä Alppien uumeniin, rakentanut valtaisat kaupungit, seilannut kaikilla maailman merillä sekä tuprutellut teollisuudestaan "kaasuja ja päästöjä ilmakehään" [sic]. Luomiskertomukselle uskollisena pysyneen Stoppanin mukaan antropotsooinen aika alkoi ihmisen luomisesta, sillä se toi Maan geologiseen historiaan absoluuttisesti uuden olion, "uuden elementin, uuden maanpäällisen voiman (engl. telluric force), joka vaikuttavuutensa ja universaaliutensa johdosta ei kalpene maapallon suurimpien voimien rinnalla”. ${ }^{1}$ Stoppani oli tiettävästi ensimmäinen, joka ehdotti ihmisvaikutuksen huomioimista geologisessa aikajärjestyksessä.

Vajaat satakolmekymmentä vuotta myöhemmin kemisti Paul Crutzen ja biologi Eugene Stoermer (2000) popularisoivat Stoppania läheisesti muistuttavin sanankääntein väitteen antroposeenis$\mathrm{ta}^{2}$. Sen mukaan ihmiskunnasta oli tullut maapalloa pysyvästi ja syvällisesti muuttava geologinen voima, joka vetää vertoja muille suurille luonnon voimille (great forces of nature), kuten asteroideille tai tulivuorenpurkauksille. Tieteellisen yhteisön olikin syytä vakavasti arvioida, oliko maapallo siirtynyt ihmisvaikutuksen vuoksi holoseenista uuteen geologiseen epookkiin, antroposeeniin.

Sittemmin antroposeenin käsitteestä on kiistelty kiihtyvästi. 2000-luvun ensimmäisellä vuosikymmenellä käsitteestä keskustelivat lähinnä geologit ja muut luonnontieteilijät. Nopea tilastollinen tarkastelu osoittaa, että erityisesti vuoden 2011 jälkeen antroposeenia käsittelevien julkaisujen määrä kuitenkin kasvaa eksponentiaalisesti ${ }^{3}$. Kuluvalla vuosikymmenellä käsitteestä onkin tullut yhä useammin myös humanistien ja yhteiskuntatieteilijöiden tutkimuksen sekä populaarien kirjoitusten ja taiteellisten hankkeiden kohde. Jotkut sanovat, että antroposeenista on jo tullut samankaltainen akateeminen iskusana kuin globalisaatio oli reilu pari vuosikymmentä takaperin.

Vaikka antroposeeni-termille löytyy luovia uusia käyttökohteita ja konteksteja ja vaikka termin merkityksestä kiistellään yhä laajemmin, voisi väittää, että antroposeenia määrittää vieläkin liiaksi sen yhteys luonnontieteiden sanastoon ja ratkaisuehdotuksiin. Tämä sidos aiheuttaa sen, että antroposeenista käytävässä keskustelussa kiistellään maapallon tilaa koskevista tieteellisistä tuloksista ja niiden tulkinnasta, ei niinkään esimerkiksi siitä, millä tavalla tieteet ovat itse olleet mukana siinä prosessissa, jonka tuloksena kestämättömäksi osoittautunut länsimainen moderni elämäntapa on syntynyt. Yhteiskunnallisena ja päivänpoliittisena asiana antroposeeniteesi onkin aivan erityinen siksi, että sen edessä päädytään väistämättä hyvin perustaviin hankaluuksiin. Antroposeenissa ei ole kyse vain yksittäisistä tosiasioista, tieteen tuloksista ja niiden oikeasta tulkinnasta, siis epistemologiasta, vaan oleellisella tavalla keskustelun ontologisista sitoumuksista. Tuskin missään yhteiskunnallisen ajattelun kohtaamassa asiassa on nimittäin hankalampaa tietää, mistä itse asiassa puhutaan: Mitä on se luonto, jonka ihmisen toiminta on tuhoamassa? Mitä on se politiikka, jota "me ihmiset" olemme tähän saakka toteuttaneet ajaaksemme meidän ihmisten yhteistä etua ja jonka nyt täytyisi ottaa ensimmäistä kertaa huomioon myös meidän planeettamme?

Vaikka siis esimerkiksi ilmastonmuutos on tieteen näkökulmasta ilmiönä päivänselvä, sitä koskeva keskustelu on hankala poikkeuksellisella tavalla. Se ylittää tavallisen tieteellisen ja poliittisen debatin siksi, että keskustelun ytimessä toimiva erimielisyys ei koske vain faktoja vaan myös niitä perustavanlaatuisia eroja, jotka yhteiskunnallisina, sukupuolittuneina, rodullistuneina ja maantieteellisinä tuottavat nämä tosiasiat. Mistä asemasta antroposeeni-keskustelun tosiasiat todetaan? Kenen ääni kuullaan? Millä termeillä globaalien ympäristökriisien edessä tehtävistä poliittisista 
päätöksistä pitäisi ylipäätään keskustella? Voiko politiikkaa todella tehdä globaalista näkökulmasta ja koko ihmiskunnan nimissä kuten antroposeeniteesi vaikuttaa ehdottavan?

Käsissäsi oleva Tiede E̋ edistys - teemanumero ottaa monipuoliseen kriittiseen tarkasteluun antroposeenin käsitteen ja siitä käytävän keskustelun. Numeron kirjoituksia yhdistävänä tavoitteena on paljastaa antroposeeni erojen ja ristiriitojen näyttämönä. Artikkelien tausta juontuu Tutkijaliiton kesällä 2016 järjestämään kesäkouluun ”Ei enää ihminen?”. Lisäksi teemanumeroa on täydennetty erikseen pyydetyillä puheenvuoroilla, jotka valottavat ristiriitaista antroposeeni-ilmiötä asiantuntemuksellaan. Antroposeeni-käsitteen ja sen ilmiön ristiriitaisuutta korostetaan artikkeleiden välisten hedelmällisten jännitteiden lisäksi myös tässä teemanumerossa kokeiltavan uuden käytännön kautta: numeron päättävät sen sisältöä ja kokonaisuutta koskevat Tuija Pulkkisen kriittiset huomautukset.

Antroposeeniteesi siis esittää poikkeuksellisen kookkaan väitteen. Se puhuu radikaalista ja pysyvästä muutoksesta, joka koskee maapalloa kokonaisuutena. Samalla se puhuu ominaisuuksiltaan ainulaatuisesta, universaalista muutoksentekijästä (Stoppanin "uusi elementti"), ihmiskunnasta, joka historian saatossa kasvoi maapalloa kaikkialla muuttavaksi voimaksi. Kuten Tero Toivanen ja Mikko Pelttari esittävät numeron avaavassa artikkelissaan, antroposeenista on tulossa suuri kertomus aikana, jolloin suurten kertomusten on tylsistymiseen asti toisteltu jo kuolleen. Aikaisempien suurten kertomusten sijaan se ei kuitenkaan julista esimerkiksi vapauden, oikeuksien tai demokratian kaltaisia totuuksia. Itse asiassa se esittää olevansa lainkaan nojaamatta ajatusrakennelmiin, joita nykyisessä mielipidemaastossa kutsuttaisiin ideologioiksi. Sen sijaan antroposeeniväite pyrkii tukeutumaan viime kädessä puhtaisiin tieteellisin faktoihin: ihmisen maankuoren kivikerrostumiin jättämiin jälkiin. Ja juuri näistä jäljistä nousee väitteen ehdotus ihmiskuntaa koskevista universaaleista totuuksista ja yhdenmukaisista lainalaisuuksista.

Luonnontiede, joka tähän asti on symboloinut ennen kaikkea ihmiskunnan jatkuvaa edistystä, kertookin viimeistään nyt vastaansanomattomasti, että ihmiskunnasta on kehkeytynyt ajan saatossa kaikkialle pesiytynyt turmiollinen voima, jonka vaikutuksen mahdollisena päätepisteenä on nykymuotoisten elämän edellytysten tuhoutuminen maapallolla. Ihminen on antroposeenikertomuksessa sekä tarinan kertoja että sen itsestään selvä rosvo, kuten Tuomo Alhojärvi artikkelissaan oivaltavasti huomauttaa. Tarina ei kuitenkaan pääty vain rosvon paljastumiseen, vaan antroposeenin tulevaisuuteen kurkottavaan jatko-osaan, jossa rosvosta tulee jälleen sankari. Niinpä havainto siitä, että ihmiskunta todella kykenee muuttamaan maapallon kurssia, johtaakin nyt ajatukseen ihmiskunnan täydellistymisen mahdollisuudesta: antroposeenitieteen faktoista vakuuttunut ihmiskunta ottaakin nyt maapallon ja sen luonnon tietoiseen hallintaansa teknologisin keinoin.

Puhtaimmillaan antroposeeniväite voi siis puhua vain universaalein termein: geologisissa kivikerrostumissa ei ole tilaa eroille. Susanna Lindberg toteaakin puheenvuorossaan osuvasti, että jälki hiekkarannalla ei kerro vielä paljoakaan sen tekijästä eikä jäljenjättäjän matkan suunnasta tai päämäärästä. Sikäli kun uudessa geologisessa epookissa on kyse ihmisestä, anthropoksesta, on siinä aina vähintäänkin häivähdyksen verran kyse sellaisista ihmiselle ominaisista piirteistä kuten tahdosta, päättämisestä tai valtakamppailusta - toisin sanottuna eroista ja politiikasta. Juuri tässä antroposeeniväite on kaikkein kynnettömin: kivikerrostumien ja yhteiskuntien historian, tieteen ja politiikan, faktojen ja kokemuksen välisessä katkoksessa. Kuten Ari Korhonen pyrkii artikkelissaan osoittamaan, siirtymät tosiasioista arvoarvostelmiin, tieteestä politiikkaan, yksittäisistä havainnoista etiikkaan ovatkin maapallon tilaa koskevien ilmiöiden kohdalla huomaamattomampia kuin missään muualla. Tämän seurauksena puhetavat globaalien ympäristökriisien yhteydessä ovat usein enemmän tai vähemmän moralisoivia: ilmiöt, joista luonnontieteiden lisäksi todistavat jo meidän jokapäiväiset kokemuksemmekin, vaikuttavat osoittavan ihmisen menneen liian pitkälle tai väärään suuntaan.

Kun puhetavoissa alkaa esiintyä vaatimuksia yhteisen hyvän tai universaalin ihmislajin edun tavoittelemisesta, huonosta omatunnosta tai - kuten antroposeeniteesin tapauksessakin - maalailevia saarnoja täydellisen tuhon uhkasta, maailmanlopusta, olisi jokaisen valistuksen kritiikkejä 
vähänkään tuntevan hälytyskellojen aika soida. Kuten nämä kritiikit ovat osoittaneet, valistukseen kuuluva edistysusko ei suinkaan ole viaton. Sen moralisoiva äänensävy kytkeytyy kapitalistisen tuotantomuodon historiaan yksinkertaisella tavalla: edistys muistuttaa ihmispoloa siitä äärettömästä velasta, jota tämän on tunnettava ylevää ihmisluontoa ja vapautta kohtaan. Edistys pakottaa hyväksymään sen, että yhteiskunnallisesti vaikuttavia tekijöitä ovat arvot, ideaalit ja universaalit päämäärät, eivät erojen ja valtasuhteiden läpäisemät yksittäiset kokemukset. Samalla kun valistuksen hengessä luodaan toivo ihmiskunnan yhteisestä hyvästä ja edistymisestä, ei pelkästään pakoteta ihmisiä irti primitiivisestä maasta vaan myös ihmisten kesken rakennetuista teknisistä ja edistyksellisistä vaihtoehtoisista elämän- ja tuotannonmuodoista, joiden ainoa virhe on olla sopimatta globaalin talouden ja pääoman logiikkaan. Antroposeeniväitteeseen liittyvistä kysymyksistä eräs keskeisimmistä onkin, miten sen olettama ihmisen historia suhteutuu kapitalismin historiaan. Jaakko Karhunen selvittääkin artikkelissaan Félix Guattarin ajatteluun sisältyvää pyrkimystä etsiä kapitalismia edeltävä poliittisen yhteisön malli ja käy samalla yleisemmin läpi sitä, millaisia ongelmia jälkikapitalistisiksi ja posthumanistisiksi sanottuihin käsityksiin sisältyy.

Antroposeeniväitteellä on kotiläksyjä tekemättä kriittisen ajattelun perusteeseistä. Sikäli kun Marx asettui valistuksen hankkeen aatehistorian kanssa vastahankaan, teki hän sen erityisesti kahdella tavalla. Ensinnäkin niin sanottua alkuperäistä kasautumista koskevilla huomiolla hän halusi tehdä jyrkän eron erityisesti klassisen poliittisen taloustieteen käsityksiin kapitalistisen talouden kehityksestä. Toisin kuin edeltäjilleen (ja hälyttävän usein myös nykyiselle taloushistorialle, taloustieteestä puhumattakaan), Marxille kapitalismi ei ollut vääjämättömästi markkinoiden ja kaupankäynnin laajentumisesta kehkeytynyt kehityskulku - saati ihmiskunnan korkein kehitysvaihe - vaan erojen läpäisemä historiallinen näyttämö, jossa pääoma nousi kolonialismin, orjuuden ja luokkataistelun verisestä maaperästä. Toiseksi Marxin työn eräs keskeinen piirre oli paljastaa kapitalismille ominaisten historiallisesti muuntuvien kategorioiden toiminta, etenkin elävän ihmistyön riistämistä koskevien logiikoiden osalta. Ajatuksena oli, että yhteiskunnallinen muutosvoima nousee tämän tutkimuksen kiinnittymisestä konkreettisiin tapahtumiin ja jo olemassa olevaan ihmisten kokemukseen oman työnsä ja elämän hallitsemattomuudesta. Tarkoitus ei ole sanoa, että antroposeenia koskevan tieteen tulisi olla marxilainen, mutta ilman ymmärrystä yhteiskuntiin väistämättä kuuluvista eroista ja ilman kiinnittymistä ihmiselämän tapahtumiin ja kokemuksiin antroposeenitiede joutunee seuraamaan sivusta, kun jatko-osan sankaritarina muuttuu todelliseksi painajaiseksi.

Antroposeeniteesin olisikin syytä muistuttaa tieteitä ja julkista puhetta keskeisestä käsitteellisen työn piirteestä: käsitteiden luomisella ja esittelemisellä on vaikutusta siitä huolimatta, että kyse on pelkistä sanoista. Globaalien ympäristökriisien kohdalla olisikin etsittävä käsitteitä, jotka kykenevät tuomaan esiin sen, että vaikka esimerkiksi ilmastonmuutosta koskevat tosiasiat ovatkin globaaleja, nykyinen yhteiskunnallinen tilanne - myös globaali - ruumiillistuu aina tapahtumina ja kokemuksina. Antroposeenin aikakaudella kyse on käsitteistä, jotka kykenisivät kytkeytymään kokemuksiin, jotka eivät nykyään koske pelkästään prekaarin elämän ja työn hallitsemattomuutta, vaan myös yhä useammin ihmisten jaettua kokemusta luontoon kohdistuvasta riistosta. Tällaisten kytkösten rakentuessa voisimme jo alkaa puhua antroposeenin politiikasta.

- TERO TOIVANEN \& ARI KORHONEN

\section{VIITTEET}

1. Ks. Turpin, E. \& Federighi, V. (2012) "A new element, a new force, a new input: Antonio Stoppani's Anthropozoic". Teoksessa E. Ellsworth \& J. Kruse (toim.), Making the Geologic Now, 34-41. Brooklyn: Punctum Books.

2. Crutzen, Paul \& Stoermer, Eugene (2000) "The'Anthropocene”. International Geosphere-Biosphere Programme (IGBP): Global Change Newsletter 41, 17-18.

3. Chin, A. ym. (2016) "An evolving Anthropocene for science and society”. Anthropocene 13, 1-3. 